\title{
EFFECT OF SOME TREATMENTS ON IN SITU DRY MATTER AND CRUDE PROTEIN DEGRADATION OF SOME RANGE PLANTS IN THE NORTH WEST COAST REGION, EGYPT
}

\author{
Abeer M. El-Essawy \\ Animal and Poultry Nutrition Department, Desert Research Center, El-Matarya, Cairo, Egypt.
}

(Received 19/9/2017, accepted 31/10/2017)

\section{SUMMARY}

\begin{abstract}
A n experiment was conducted to evaluate the nutritive value of six dominant range plants in Wadi Hashim, North West Coast, Egypt, through the estimation of chemical composition and in situ dry matter (DM) and crude protein (CP) degradation kinetics. In addition, plants were treated by different processes, such as ensiling or addition of Poly Ethylene Glycol (PEG) in comparison with those without treatment (as fed). The plants belong to 6 families: Thymelaea hirsuta (family: Thymelaeaceae); Lycium shawii (f: Solanaceae); Asphodelus fistulosus (f: Liliaceae); Silybium marianum (f: Compositae); Pituranthos tortuosus ( $f$ : Umbelliferae) and Suaeda vermiculata ( $f$ : Chenopodiaceae). The DM and CP degradation kinetics were evaluated by the artificial fiber bag technique through in situ procedure, using three ruminally cannulated camels. Chemical composition of the studied plants showed that Suaeda vermiculata followed by Lycium shawii contained higher CP (12.8 and 11.9\%, respectively). Treatments as ensiling process or treatment with PEG improved chemical composition of the experimental plants. Degradation profile of DM indicated that the higher values of the rapidly degradable fraction 'a' were recorded in $S$. marianum followed by A. fistulosus in all of their forms (as fed, silage or treated with PEG) while $S$. vermiculata recorded high value in silage form only (42.4\%). The fraction ' $a$ ' was generally low across the studied plants as fed and those treated with PEG. However, the slowly degradable fraction 'b' differed among plant species, being high in A. fistulosus and S. marianum with 60.4, and 59.3\% DM (as fed), 57.3 and $56.8 \%$ DM (treated with PEG) and 57.7 and $62.1 \%$ DM (when ensiled), respectively. Concerning the CP degradability, it was found that the soluble fraction "a" was low as in T. hirsute, P. tortuosus and $S$. vermiculata (as fed, 10.5, 21.7 and $23.5 \% \mathrm{CP}$, respectively) and it was irregularly affected with PEG addition to become $31.5,23.5$ and $19.6 \% \mathrm{CP}$, respectively, and slightly increased when ensiled to become $24.5,23.4$ and $31.2 \% \mathrm{CP}$, respectively. Meanwhile, the slowly fraction "b" was not affected in a uniform pattern when treated with PEG or ensiled. The slowly fraction was reduced in $T$. hirsute and A. fistulosus when treated with PEG or ensiled when compared with their values as fed. Results indicated that the contents of antinutritional factors, total and condensed tannins and saponin, in the studied plants were reduced with treatment, particularly ensiled ones. Based on these findings, it can be concluded that the nutritive value of the forage plant species are improved with treatment and can be used as supplement when ensiled.
\end{abstract}

Keywords: range plants, in situ, nutritive value, dry matter and crude protein degradation, poly ethylene glycol

\section{INTRODUCTION}

Forage plants, constitute one of the cheapest sources of feed for ruminants. In the meantime, browsing tree foliage plays an important role in ruminant feeding systems in many Mediterranean and tropical environments around the world (Kumara Mahipala et al., 2009). As a result to their resistance to heat, drought, salinity, alkalinity, drifting sand, grazing and repeated cutting, they are the major feed resources during the dry season (Fagg and Stewart, 1994). They are chiefly considered as good, cheap sources of nitrogen and energy, which may reduce feeding cost and raise sheep productivity in arid and semi-arid zone (FAO, 1987).

However, the problems of feeding such plants or shrubs such as Thymelaea hirsuta (family: Thymelaeaceae); Lycium shawii ( $f$ : Solanaceae); Asphodelus fistulosus (f: Liliaceae); Silybium 


\section{El-Essawy}

marianum (f: Compositae); Pituranthos tortuosus ( $f$ : Umbelliferae) and Suaeda vermiculata ( $f$ : Chenopodiaceae) that they have different levels of anti-nutritional factors. Also, they are rich in fiber and some of them are deficient in protein. The previous plants are dominant in Wadi Hashim in the North West coast region of Egypt. Bedouins in this region nowadays pay much attention in just feeding their livestock with any locally or costly available feed materials without knowing the digestibility and nutritive values of such plants.

Unfortunately many forage trees and shrub legumes contain anti-nutritive or secondary compounds that can seriously restrict their value as animal feeds. Moreover, anti-nutritional factors (ANFs) are substances that when present in animal feed or water they either by themselves or through their metabolic products reduce the availability of one or more nutrients. Therefore, a practical strategy for overcoming ANF could involve to reduce their levels in the diet and ruminal detoxication may be able to cope with low levels of toxin in some cases (Lowry, 1989; Jones and Lowry, 1991).

The major anti-nutritive factors in browse plants are tannins and saponins. Tannins have both beneficial and adverse effects. Beneficial effects of tannins include suppression of bloat (Jones et al., 1973), protection of dietary proteins in the rumen (Waghorn et al.,1994) also, they had anti-diarrhea, anti-bacterial and anti-oxidant properties. Not only that, but they can work as protein protection during ensilage (Yacout , 2016). The adverse effects of tannins are associated with their ability to bind with dietary proteins, carbohydrates and minerals (McSweeney et al., 2001) cause decreased palatability, feed intake and growth rate (Roeder, 1995). Tree and shrub leaves contain the two different groups (hydrolysable \& condensed Tannins (CT)). Condensed Tannins have more effect in reducing digestibility than hydrolysable tannins because of their ability to form strong hydrogen bonds with nutrients resulting in inhibitions of digestive enzymes and rumen microbial activity (Kumar and Singh (1984).

Saponins are a heterogenous group of naturally occurring foam producing steroidal glycosides that occur in a wide range of plants (Jenkins and Atwal (1994). Meantime, they can cause bloat, hemolysis and inhibit microbial fermentation and synthesis in rumen ( $\mathrm{Lu}$ and Jorgensen, (1987). A number of methods have been tried to overcome the deleterious effect of such anti-nutritional factors and tannins. These are through making hay, silage, using PEG (Ben Salem et al., 2000 ; Salem et al., 2007) which can be applied to either take off or minimized and decrease anti-nutritional factors concentration. Improving forage quality by reducing proteolysis during ensiling will improve $\mathrm{N}$ utilization by ruminants (Givens and Rulquin, 2004). Moreover, It is well known that alkali treatment includes polyethylene glycol (PEG), which a tannins-binding agent (Jones and Mangan, 1977), was shown to be a powerful tool for isolating the effect of tannins on various digestive function (Makkar et al., 1995). Nowadays, the artificial bag technique (Meherez and Ørskov, 1977) is the standard technique in feed evaluation system (Tamminga et al., 1994; Thomas, 2004).

This study is designed to: 1) evaluate the nutritive values of six dominant range plants in Wadi Hashim, North West Coast, Egypt. 2) To evaluate the dry matter (DM) and crude protein (CP) degradation characteristics of the selected plants . 3)To evaluate the best treatment that improve the utilization of the studied plants such as ensiling or addition of Poly Ethylene Glycol (PEG) compared with those without treatment (as fed). Also, 4) To determine the proximate composition and antinutritive profile of the selected plants in the study areas. Finally, 5) To recommend the appropriate forage plants to Bedouins to augment feed supplies where these plants are locally readily available and commonly fed to ruminant.

\section{MATERIALS AND METHODS}

\section{Study area and samples:}

Six common plant species in this area were used in this experiment. The species were Thymelaea hirsuta ; Lycium shawii ; Asphodelus fistulosus ; Silybium marianum ; Pituranthos tortuosus and Suaeda vermiculata. All plant species were harvested during winter season (January, 2010) from Wadi Hashim, North Western coast, Egypt. The experimented plant species were harvested from at least 10 trees per each selected species at random in four locations within the study area .

Samples preparation: 
Samples of each plant species were individually divided into three portions: one portion was ensiled to make silage, the other two portions of each plant samples were air dried and milled. One of these two portions used as fed and the other one was sprayed with 5\% g polyethylene glycol PEG $(\mathrm{MW}=4000)$ solution.

Silage preparation: Enough amounts of edible parts of the fresh plants were allowed to wilt separately to an average $40 \%$ dry matter (DM), then chopped and mixed thoroughly with sugar cane molasses in proportions of $90: 10$ on dry matter (DM) basis. Each plant was ensiled and covered for anaerobic fermentation for 45 days in small hard plastic barrels with tight sealed cover. Each ensiled plant was labeled and stored for degradability study and for chemical analysis.

Polyethylene glycol (PEG) treatment: enough amounts of edible parts of each plant were cut and spreading the cut parts of each plant separately on a thin plastic sheet to avoid mechanical losses and sand contamination, then air dried separately. Dried plants were sprayed with 4\% PEG (molecular weight 4000) (Sigma chemical company, UK) solution, (12 g PEG for $1 \mathrm{~kg}$ DM plant) (Wina, 2010) then let to dry again before using.

Each portion was also labeled and stored in sealed bags for degradability study as well as for proximate analysis.

\section{In situ trial :}

The in situ DM and CP disappearance was conducted according to the method of Ørskov and MacDonald (1979). Camels were fed ad libitum a good quality berseem hay. Water was available at all times. Five grams samples were dried and milled through a 2-mm sieve then weighed into nylon bags to be incubated in three rumen fistulated camels as animal replicates. The size of the bag was 170 $\times 100 \mathrm{~mm}$ with average pore size of $50 \mu \mathrm{m}$. Duplicate sample bags at each time were incubated in each camel for seven incubation times ( 3, 6, 12, 24, 48, 72 and 96 hours), in reverse order before morning feeding. Considering two replicates per time and per animal for each plant species, with a total of six observations per time. A piece of marble was included in each bag containing $5 \mathrm{~g}$ sample to prevent the bag from floating in the rumen. The weight of each bag and its content was then recorded. On removal the nylon bags were thoroughly washed with pressurized tap water to remove digesta until the rinse was clear. The zero time bags $(\mathrm{T} 0 \mathrm{~h})$ were not introduced into the rumen but by soaking the bags containing the samples in warm water $\left(40^{\circ} \mathrm{C}\right)$ for $20 \mathrm{~min}$, followed by drying by the same procedures as those removed from the rumen. Bags containing forage residues were oven dried at $60{ }^{\circ} \mathrm{C}$ for $48 \mathrm{~h}$ and then reserved for later analysis.

In situ DM and CP degradation data were fitted to the following exponential equation:

$$
\mathrm{Y}=\mathrm{a}+\mathrm{b}\left(1-\mathrm{e}^{-\mathrm{ct}}\right) . \quad(\varnothing \mathrm{rskov} \text { and MacDonald , 1979) }
$$

where: $\mathrm{Y}=\mathrm{DM}$ or $\mathrm{CP}$ degradation in rumen at time $\mathrm{t}$

$\mathrm{a}=$ Water soluble (or rapidly degraded) fraction (at T0)

$\mathrm{b}=$ the slowly degradable (or potentially degradable) fraction

$\mathrm{c}=$ Rate of degradation of $\mathrm{b}$

$\mathrm{t}=$ Incubation time i.e. $2,4,6,12,24,48$ and $96 \mathrm{hrs}$

The un-degradable fraction $(U)$ was calculated as: $U=100-(\mathrm{a}+\mathrm{b})$. Effective degradability (ED) of $\mathrm{DM}$ and $\mathrm{CP}$ was calculated as: $\mathrm{ED}=\mathrm{a}+[(\mathrm{b} \times \mathrm{c}) /(\mathrm{c}+\mathrm{k})]$, assuming constant rumen passage rates (k) of 0.02, 0.05 and $0.08 \mathrm{~h}^{-1}$ for each ingredient. (Ørskov and MacDonald , 1979)

\section{Chemical analysis:}

Chemical component analysis of samples and the residues in the bags were individually analysed for dry matter (DM), crude protein (CP), ether extracts (EE) and ash contents were determined according to AOAC, (2005). Anti-nutritional constituents were determined in forages include: total tannins using copper acetate according to Balbaa (1969), condensed tannins (leucocyanidin equivalent) was estimated by the butanol- $\mathrm{HCl}$ method of Porter et al. (1986) and saponins as reported by Okwu and Ukanwa (2007), respectively. All chemical analyses were done in triplicate.

\section{Statistical analysis:}




\section{El-Essawy}

Degradation parameters of DM and CP of forage plants during rumen incubation were calculated following the model proposed by Ørskov and McDonald (1979), as mentioned above and using the non-linear regression procedure (PROC NLIN) of the SAS statistical package (version 9.0; SAS). Data of the degradation parameters ( $a, b, c, E D$, and total degradable and un-degradable parameters) were separately analyzed by the GLM procedure of the SAS statistical package, with a model consisting of the effects of plant species, treatments and their interaction. Differences between means are significant when $\mathrm{P}$ - value is below 0.05 .

\section{RESULTS AND DISCUSSION}

Concerning to the palatability, the experimented plants were classified according to the previous studies of El-Morsy (2010) and El-Morsy and Ahmed (2010) (Table 1). The plants were divided into three types: 1) Palatable plants such as Lycium shawii and Asphodelus fistulosus. 2) less palatable or undesirable including Pituranthos tortuosus and 3) unpalatable including Thymelaea hirsute, Silybium marianum and Suaeda vermiculata.

Table (1). Palatability of the studied plants

\begin{tabular}{|c|c|c|c|c|}
\hline Family name & Scientific name & Palatability & Life duration & Vernacular name \\
\hline Thymelaceae & Thymelaea hirsuta & UP & Per & Methanan \\
\hline Solanaceae & Lycium shawii & $\mathrm{P}$ & Per & Awsage \\
\hline Liliaceae & Asphodelus Fistulosus & $\mathrm{P}$ & Per & Basal El-onsol \\
\hline Compositae & Silybium marianum & UP & Per & Shoak El-Gamal \\
\hline Umbelliferae & Pituranthos tortuosus & LP & Per & Qozzah \\
\hline Chenopodiaceae & Suaeda vermiculata & UP & Per & Soweid \\
\hline
\end{tabular}

\section{Chemical composition of the browse forages:}

The results of (Table 2) showed that the chemical composition of the studied plants was considerably affected with different treatments. Results of dry matter (DM) content as fed ranged from $92.72 \%$ (Asphodelus fistulosus) to $96.74 \%$ (Suaeda vermiculata), while it decreased when treated with PEG to range from $90.6 \%$ (Silybium marianum) to $92.04 \%$ (Thymelaea hirsute) and when treated as silage from $85.67 \%$ (Suaeda vermiculata) to $92 \%$ (Pituranthos tortuosus). The organic matter (OM) contents revealed the lowest values with all treated forms of Suaeda vermiculata. On the other hand, the highest values were recorded with Pituranthos tortuosus, in all of its forms of treatments. Generally, CP and CF contents of the treated plants with PEG and as silage were improved especially in silage form. It was noticed that a higher CP content in most plants was associated with a lower CF content in silage form and PEG. The results indicated that ensiling procedure increased the breakdown of CF resulting in decreasing its values (El-Waziry, 2007). This means that ensiling process improves the nutritive value of the experimental plants. Moreover, decreasing of CP or total ash (TA) may be due to the soluble parts of them that lost during ensiling (in case of silage) or during drying of plants before and after PEG spraying. Interestingly, the results showed an increment in nitrogen free extract (NFE) in some plants during ensiling or with PEG spraying which could be attributed to the increasing of CF breakdown.

Liman et al. (2016) reported that browse plants with CP level below 7\% are considered deficient and therefore may not sustain live weight of animals; such plants may only be supplemented by protein feed sources. The CP contents of the studied plants were generally moderate (above 7\%) but it was low (less than 7\%) in only two of them. Generally, the CP content in plants has been shown to be above the minimum level required for microbial activities in the rumen (Norton, 1998 and Njidda et al., 2013). On the other hand, Le Houerou (1980) also noted that all browse species are able, in all 
their growth stages, to meet the energy requirements of livestock at maintenance level and often well above. The difference in CP contents among plant species can be explained by inherent characteristics of each species related to the ability to extract and accumulate nutrients from soil and/or to fix atmospheric nitrogen. The other factors causing variation in the chemical composition of forages include soil type (location), the plant part (leaf, stem and pod), age and season (Njidda and Olatunji, 2012). With regard to the fiber content, the studied forages had moderate to high content of fiber but different treatments affecting their contents. As mentioned above that CF content was reduced with silage and PEG addition. Ensiling has been reported to reduce fiber content (Khan et al., 2006; Rezaei et al., 2009) and therefore could improve the nutritive value of forages. The current results are supported by reports that fiber content is reduced at ensiling (Colombatto et al., 2004). Ensiling process also causes a number of changes where Morrison (1979) showed that the lignin concentration of forage did not change while that of cellulose decreased up to 5\% during ensiling.

Table (2). Chemical composition of the experimental plants in different forms (as fed, treated with PEG and as silage) on DM\% bases.

\begin{tabular}{lccccccc}
\hline Plant & DM & OM & TA & CP & CF & EE & NFE \\
\hline Thymelaea hirsute & & & & & & & \\
As fed & 95.6 & 92.8 & 7.20 & 6.9 & 27.1 & 5.0 & 53.7 \\
PEG & 92.0 & 93.2 & 6.80 & 6.9 & 25.9 & 2.6 & 57.8 \\
Silage & 91.7 & 89.3 & 10.70 & 8.2 & 24.8 & 2.3 & 54.0 \\
Lycium shawii & & & & & & & \\
As fed & 96.2 & 88.6 & 11.4 & 11.9 & 27.6 & 3.1 & 46.0 \\
PEG & 91.5 & 92.9 & 7.1 & 11.8 & 18.2 & 0.23 & 62.6 \\
Silage & 91.3 & 87.7 & 12.3 & 12.8 & 15.6 & 1.1 & 40.3 \\
Asphodelus Fistulosus & & & & & & & \\
As fed & 92.7 & 85.0 & 15.0 & 10.4 & 23.3 & 4.9 & 46.3 \\
PEG & 90.7 & 86.4 & 13.6 & 12.3 & 21.3 & 3.9 & 48.8 \\
Silage & 88.6 & 82.5 & 17.5 & 11.2 & 14.4 & 2.8 & 54.1 \\
Silybium marianum & & & & & & & \\
As fed & 94.2 & 86.2 & 13.8 & 10.8 & 16.7 & 4.2 & 54.5 \\
PEG & 90.6 & 85.5 & 14.5 & 8.6 & 15.7 & 2.8 & 58.5 \\
Silage & 89.0 & 83.8 & 16.2 & 12.7 & 12.9 & 2.1 & 56.1 \\
Pituranthos tortuosus & & & & & & & \\
As fed & 95.7 & 93.6 & 6.4 & 6.4 & 43.6 & 3.5 & 40.2 \\
PEG & 91.2 & 94.5 & 5.5 & 6.3 & 26.5 & 1.7 & 59.9 \\
Silage & 92.0 & 91.8 & 8.2 & 7.7 & 17.7 & 1.8 & 66.6 \\
Suaeda vermiculata & & & & & & & \\
As fed & 96.7 & 82.5 & 17.5 & 12.8 & 24.3 & 3.6 & 41.8 \\
PEG & 91.1 & 81.8 & 18.2 & 11.5 & 17.5 & 1.9 & 50.9 \\
Silage & 85.7 & 81.3 & 18.7 & 12.7 & 14.3 & 2.2 & 32.1 \\
\hline
\end{tabular}

DM: dry matter; OM: organic matter; TA: total ash; CP: crude protein; CF: crude fiber; EE: ether extract; NFE: nitrogen free extract. PEG: poly ethylene glycol

\section{Anti-nutritional factors levels of the forages:}

Phytochemical screening of the studied plants as fed revealed the presence of tannins in all six studied plants and saponin in only three plants as major constituents.

Ensiling the tested plants and treatment with PEG led to decrease all secondary metabolites contents compared with raw materials (Table 3). The highest contents of total tannins (TT) as fed were observed in Lycium shawii (4.9\%) whereas Pituranthos tortuosus and Suaeda vermiculata plants showed lowest concentrations ( 0.9 and $0.5 \%$, respectively). On the other hand, condensed tannins (CT) varied widely among plants as fed, the highest value was recorded for Thymelaea hirsuta (2.9\%) while the lowest value was recorded for Suaeda vermiculata $(0.08 \%)$. In addition, treated selected plant with PEG led to decrease their contents of tannins. These results agree with findings of Makkar (2003b) who used PEG as a tannin complexing agent to inhibit their biological effect. Boufennara et al. (2013) reported that the blocking effect of PEG on tannins would be an indicator of the biological activity of tannins on rumen microbial fermentation. In fact, PEG binds 


\section{El-Essawy}

tannins and inactivates it by reducing its anti-nutritional effect, and recovers feed nutrients bound by tannins (Canbolat et al., 2005; Rubanza et al., 2005). The level of tannin which adversely affect digestibility in ruminants is between $2 \%$ and $5 \%$ (Gidado et al., 2013).

Table (3). Anti-nutritional factors in the forages plants

\begin{tabular}{|c|c|c|c|}
\hline Plant & TT g\% & CT $\mathrm{mg} \%$ & Sap g\% \\
\hline \multicolumn{4}{|c|}{ Thymelaea hirsute } \\
\hline As fed & 4.8 & 2.9 & 5.1 \\
\hline PEG & 3.0 & 1.0 & 4.3 \\
\hline Silage & 3.1 & 1.8 & 3.9 \\
\hline \multicolumn{4}{|c|}{ Lycium shawii } \\
\hline As fed & 4.9 & 1.5 & 7.6 \\
\hline PEG & 2.0 & n.e & 3.6 \\
\hline Silage & 2.3 & 0.6 & 4.1 \\
\hline \multicolumn{4}{|c|}{ Asphodelus Fistulosus } \\
\hline As fed & 4.7 & 1.8 & n.e \\
\hline PEG & 3.0 & 0.9 & n.e \\
\hline Silage & 3.3 & 1.0 & n.e \\
\hline \multicolumn{4}{|c|}{ Silybium marianum } \\
\hline As fed & 4.6 & 1.4 & n.e \\
\hline PEG & 3.5 & 1.1 & n.e \\
\hline Silage & 3.8 & 1.2 & n.e \\
\hline \multicolumn{4}{|c|}{ Pituranthos tortuosus } \\
\hline As fed & 0.9 & 0.6 & 3.4 \\
\hline PEG & n.e & n.e. & 2.3 \\
\hline Silage & n.e & n.e & 1.7 \\
\hline \multicolumn{4}{|c|}{ Suaeda vermiculata } \\
\hline As fed & 0.5 & 0.1 & n.e \\
\hline PEG & n.e & n.e & n.e \\
\hline Silage & n.e & n.e & n.e \\
\hline
\end{tabular}

TT: total tannins; CT: condensed tannin; Sap: saponins

PEG: poly ethylene glycol; n.e: not evaluated

Due to its property to bind with condensed tannins (CT), PEG has been used to reduce the adverse effects of CT in ruminant diets (Silanikove et al., 1994; Barry and McNabb, 1999; Jones and Palmer, 2000; McSweeney et al., 2001).

Ensiling the experimental plants individually as a process to ameliorate the anti-nutritional factors effect indicated that ensiling the forages showed comparable results of CT to PEG treatment. ElWaziry et al. (2007) concluded that ensiling processing decreased tannins and ash content in acacia and atriplex, respectively.

Concerning saponin levels, the PEG addition and ensiling reduce saponin levels compared to those as fed. The highest concentration of saponin as fed was recorded in Lycium shawii reduced when treated with PEG or ensiled (7.6\% vs. 3.6 or $4.1 \%$, respectively). Gidado et al. (2013) suggested tolerated level of saponins in ruminant diet ranged from 1.5 to $2 \%$. Inhibition of rumen proteolytic activity of saponins has been demonstrated (Wallace et al., 1994). Saponins also form complexes with proteins and could decrease protein degradability (Sen et al., 1998). The effect of saponins could differ from feed type to other, Makkar and Becker (2000) reported that quillaja saponins decreased protein degradability of the concentrate, but not of hay-based diet. The current data are the first report about the in situ degradability of the studied plants in camels.

\section{Ruminal Degradation Profiles:}

Degradation kinetics profile of DM (Table 4) indicated that the higher values of the rapidly degradable fraction 'a' was recorded in Silybium marianum treated with PEG and silage of Suaeda vermiculata when compared with their corresponding values as fed with significant variations $(\mathrm{P}<$ 0.01 ). The slowly degradable or insoluble dry matter fraction ' $b$ ' was not significantly affected with treatments. It differed among the investigated plants and mostly high in Asphodelus fistulosus and Silybium marianum, in the two treated forms when compared with as fed plants $57.3 \%$ and $56.8 \%$ DM (treated with PEG) and $57.7 \%$ and $62.1 \%$ (when ensiled), respectively. This observation may 
probably be due to it's cell wall content (Wilson, 1994). In other words, fresh forage is degraded extensively in the rumen but the distribution of morphological components is not the same, resulting in a differential degradation of nutrient fractions in the rumen (Valderrama and Anrique, 2011). The rate of degradability 'c' of DM $(\mathrm{DMc})$ significantly $(\mathrm{P}<0.01)$ affected with treatments in a non uniform pattern. Total or potential degradation ' $a+b$ ' of dry matter was affected significantly $(\mathrm{P}<0.01)$ with treatment, it was above 50\% in most of the plants. However, according to Singh and Makkar (1993) the statistical variations may be associated with their fibrous components such as the structural polysaccharides, which vary in their degradation among forages. The highest values of potential degradability reported here were recorded in Silybium marianum: $88.2 \%$ (as fed), 87.9\% (treated with PEG) and $94.6 \%$ (when ensiled) and it was associated with the presence of large quantities of soluble fraction ' $a$ ' and high degradability of slowly degradable fraction $b$, resulting in low amounts of undegradable fraction $\mathrm{U}(\mathrm{P}<0.01) 11.8 \%$ as fed, $12.1 \%$ (treated with $\mathrm{PEG)}$ and $5.4 \%$ (when ensiled), respectively. Most of the studied plants followed the same pattern. Valderrama and Anrique (2011) reported similar concept . Costa et al. (2016) found that the DM degradability of silage without tannin showed higher soluble fraction and higher degradation potential. The greater soluble fraction of this silage is in accordance with the highest degradation rate of this material. The higher the soluble fraction and the degradation potential of a food, the higher the degradation rate. The effective degradation in the rumen depends on how long the feed remains in the rumen which is also a function of the quality of the feeds fed to the animals. The effective degradability of dry matter in the investigated plants varied significantly $(\mathrm{P}<0.01)$. The highest effective degradability $(\mathrm{ED})$ values (80.9\% and $80.2 \%$ as fed vs. 80.8 and $80.1 \%$ when treated with PEG and 87 and $84.6 \%$ when ensiled) were observed in Silybium marianum and Asphodelus fistulosus in all of their forms (as fed vs. PEG and silage ), respectively. while the lowest values (35\% vs. $44.5 \%$ ) were obtained in Pituranthos tortuosus (as fed vs. silage) and (41.1\%) in Lycium shawii (when treated with PEG) at the fractional out flow rate of $\mathrm{k}=0.02$. These findings could be attributed to moderate contents of $\mathrm{CP}$ and $\mathrm{CF}$ in these plants as previously reported in Table (2). Mupangwa et al. (2003) found that variations in effective degradability of dry matter in forages closely corresponds with the proportion of potentially degradable dry matter and level of NDF. Also, Llamas-Lamas and Combs (1990) have observed that forages with low fiber to have high effective dry matter degradability compared to those with high fiber content. Abdel Gawad (2015) reported that increasing the acid detergent fiber and on contrary decreasing the neutral detergent fiber could be the reason for the significant reduction of in situ DM degradation. Generally, Liman et al. (2016) found that degradability decreased with increasing fiber content. To specify the effect of plant species on degradation Kinetics profile of DM, It is clear that plant species highly affected degradation values of DM. Concerning treatment effect, it also affects all values of profile except slowly degradable fraction. Consequently, plant - treatment interaction was significantly affecting the DM degradation profile.

Concerning the degradation profile for in situ $\mathrm{CP}$ of the forage plants (Table $4 \mathrm{~A}$ and $\mathrm{B}$ ) and Figure 1), it was found that the soluble CP fraction "a" (Cpa) was low as in Thymelaea hirsute, Pituranthos tortuosus and Suaeda vermiculata (as fed), 10.5, 21.7 and 23.5, respectively) and it was irregularly affected with PEG addition to become (31.5, 23.5 and 19.6, respectively) and slightly increased when ensiled to become $(24.5,23.4$ and 31.5, respectively). However, CPa fraction of Lycium shawii was considerably decreased when treated with PEG (32.5 vs. 1.5 for as fed and PEG addition) respectively. Besides, milled feed particle size has been shown to affect soluble CP fraction (Gonzalez and Andres, 2003). Nevertheless, Wallace and Gotta (1988) recorded that in high soluble protein fractions may stimulate proteolysis bacteria in the rumen. Dealing with the values of slowly degradable fraction of $\mathrm{CP}(\mathrm{CPb})$, it was not affected significantly in a uniform pattern when treated with PEG or ensiled as a silage compared with their values as fed. For CP, the observed variations in degradability may be due to complexes formed between tannins and proteins. These complexes mostly insoluble in the neutral detergent and could add to the un-degradable fraction (Makkar et al., 1995). The same author reported that the addition of PEG decrease the degradability due to occurrence of tannin - PEG complexes. Moreover, a decrease in "a" values and an increase in b-values was observed when PEG was supplied. The addition of PEG increased the availability of protein to rumen micro-organisms by releasing protein from tannin - protein complexes (Makkar et al., 1995a). Thus, reducing protein degradation in the rumen is one of the major causes for in efficient utilization of protein in ruminants (Pathak, 2008). The degradation rate "c" of CP in the current study (CPc) was non significantly affected with treatment. The $\mathrm{CPc}$ is related to forage quality and type (Vanzant $e t$ al., 1996). On the other hand, differences in degradation rates could be due to amounts of intracellular components and digestibility, while $\mathrm{N}$ availability is due to its distribution among cell structures (Valderrama and Anrique, 2011). Many studies reported decreases in DM and CP ruminal degradation rates in the presence of condensed tannins (Barry and McNabb, 1999; Foley et al. 1999; 


\section{El-Essawy}

McMahon et al., 2000). The total degradability " $\mathrm{a}+\mathrm{b}$ " values of CP were comparable with each other in different forms. Newman et al. (2002), believed that long lag times influence the degree that the slowly degraded fraction "b" is broken down in the rumen. Brown et al. (1991) have showed that with low supply of nitrogen to the rumen and long lag phase for CP degradation, high concentrations of insoluble but degradable CP will mostly pass to the lower digestive tract before being degraded. However, effective CP degradability (ED2) was not affected by PEG supply or ensiling. On the other hand Njidda et al. (2013) studied that feeding tannin containing plant can decrease ruminal protein degradation and promote the efficiency of microbial protein synthesis (Cardozo et al., 2004). However, in ruminants, dietary condensed tannins of 2 to $3 \% \mathrm{DM}$ have beneficial effects because they reduce the protein degradation in the rumen by the formation of a protein - tannin complex (Barry, 1987) and increasing absorption of amino acids in the small intestine (Barry and McNabb, 1999). On this basis, they proposed as feed additives to improve digestive utilization of dietary protein (Schwab, 1995). Moderate levels of CT $(3-4.5 \%$ DM) can exert beneficial effects on protein metabolism in ruminants, but high levels of CT (> 5.5\% DM) can depress voluntary feed intake, digestive efficiency and animal productivity. The effects can vary depending on tannin type, concentration, and animal species (Makkar, 2003). The effective degradability (ED) of CP in the current study at an outflow rate of $2 \%, 5 \%$ and $8 \%$ per hour were variable from plant to plant and considerably significantly $(\mathrm{P}<0.01)$ affected with different treatments at passage rate of 5 and $8 \%$. High effective degradability (ED) of CP values can arise from high value of soluble fraction and rate of passage of feed through the rumen (Gonzalez and Andres, 2003). Concerning the effect of plant species, it is clear that it affects significantly on degradation profile for in situ $\mathrm{CP}$ of the forage plants. However, different treatments are affecting most of values of CP degradation profile. So, plant - treatment interaction revealed high significant action on degradation profile of $\mathrm{CP}$.

Table (4). Degradation fractions (a, b, U) and effective degradability (ED) of dry matter (DM) (A) and crude protein $(\mathrm{CP})(\mathrm{B})$ of forages $(\%)$ at ruminal outflow rates of $0.02,0.05$ and 0.08 h-1.

(A)

\begin{tabular}{|c|c|c|c|c|c|c|c|c|}
\hline Forage DM & $\mathrm{a}$ & B & $\mathrm{U}$ & $a+b$ & $\mathrm{c}$ & $\begin{array}{c}\text { EDdm } \\
\mathrm{k}=0.02 \mathrm{~h}-1\end{array}$ & $\begin{array}{c}\text { EDdm } \\
\mathrm{k}=0.05 \mathrm{~h}-1\end{array}$ & $\begin{array}{c}\text { EDdm } \\
\mathrm{k}=0.08 \mathrm{~h}-1\end{array}$ \\
\hline \multicolumn{9}{|c|}{ Thymelaea hirsute } \\
\hline As fed & 7.7 & 53.5 & 38.9 & 61.1 & 0.24 & 56.6 & 51.1 & 46.8 \\
\hline PEG & 5.8 & 56.1 & 38.1 & 61.9 & 0.39 & 59.1 & 55.3 & 52.1 \\
\hline Silage & 3.4 & 59.4 & 37.2 & 62.8 & 0.29 & 58.9 & 54.1 & 50.1 \\
\hline \multicolumn{9}{|c|}{ Lycium shawii } \\
\hline As fed & 8.9 & 28.7 & 62.3 & 38.7 & 0.26 & 35.4 & 32.6 & 30.4 \\
\hline PEG & 9.7 & 32.9 & 57.4 & 42.6 & 0.43 & 41.1 & 39.1 & 37.3 \\
\hline Silage & 24.9 & 35.8 & 39.3 & 60.7 & 0.18 & 57.0 & 52.8 & 49.6 \\
\hline \multicolumn{9}{|c|}{ Asphodelus fistulosus } \\
\hline As fed & 25.5 & 60.4 & 14.1 & 85.9 & 0.19 & 80.2 & 73.5 & 68.2 \\
\hline PEG & 28.2 & 57.3 & 14.5 & 85.5 & 0.20 & 80.1 & 73.8 & 68.9 \\
\hline Silage & 33.8 & 57.7 & 8.5 & 91.5 & 0.15 & 84.6 & 76.8 & 71.2 \\
\hline \multicolumn{9}{|c|}{ Silybium marianum } \\
\hline As fed & 28.9 & 59.3 & 11.8 & 88.2 & 0.15 & 80.9 & 73.0 & 67.2 \\
\hline PEG & 31.1 & 56.8 & 12.1 & 87.9 & 0.15 & 80.8 & 73.1 & 67.4 \\
\hline Silage & 32.5 & 62.1 & 5.4 & 94.6 & 0.15 & 87.0 & 78.7 & 72.6 \\
\hline \multicolumn{9}{|c|}{ Pituranthos tortuosus } \\
\hline As fed & 9.1 & 29.4 & 61.6 & 38.5 & 0.15 & 35.0 & 31.2 & 28.3 \\
\hline PEG & 10.2 & 34.5 & 55.3 & 44.7 & 0.26 & 42.2 & 39.1 & 36.5 \\
\hline Silage & 14.6 & 32.9 & 52.5 & 47.5 & 0.19 & 44.5 & 40.8 & 37.9 \\
\hline \multicolumn{9}{|c|}{ Suaeda vermiculata } \\
\hline As fed & 19.9 & 33.8 & 46.3 & 53.7 & 0.12 & 48.7 & 43.5 & 39.9 \\
\hline PEG & 21.5 & 36.3 & 42.2 & 57.8 & 0.19 & 44.5 & 50.4 & 47.3 \\
\hline Silage & 42.4 & 30.6 & 27.0 & 72.9 & 0.18 & 69.9 & 66.2 & 63.5 \\
\hline$\pm \mathrm{SE}$ & 1.74 & 1.84 & 0.99 & 0.99 & 0.04 & 0.77 & 0.93 & 1.05 \\
\hline \multicolumn{9}{|l|}{ Significance } \\
\hline Plant & $* * *$ & $* * *$ & $* * *$ & $* * *$ & $* * *$ & $* * *$ & $* * *$ & $* * *$ \\
\hline
\end{tabular}


Egyptian J. Nutrition and Feeds (2017)

\begin{tabular}{lcccccccc}
\hline Treatment & $* * *$ & $\mathrm{~ns}$ & $* * *$ & $* * *$ & $* * *$ & $* * *$ & $* * *$ & $* * *$ \\
Plant $\times$ treatment & $* * *$ & 0.05 & $* * *$ & $* * *$ & $*$ & $* * *$ & $* * *$ & $* * *$ \\
\hline Table (4) Continue & & & & & & & &
\end{tabular}

Table (4). Continue

(B)

\begin{tabular}{|c|c|c|c|c|c|c|c|c|}
\hline Forage $\mathrm{P}$ & $\mathrm{a}$ & B & $\mathrm{U}$ & $a+b$ & $\mathrm{c}$ & $\begin{array}{c}\mathrm{EDp} \\
\mathrm{k}=0.02 \mathrm{~h}-1\end{array}$ & $\begin{array}{c}\mathrm{EDp} \\
\mathrm{k}=0.05 \mathrm{~h}-1\end{array}$ & $\begin{aligned} & \text { EDp } \\
\mathrm{k}= & 0.08 \mathrm{~h}-1\end{aligned}$ \\
\hline \multicolumn{9}{|l|}{ Thymelaea hirsute } \\
\hline As fed & 10.5 & 52.9 & 36.6 & 63.4 & 0.24 & 52.7 & 46.3 & 40.8 \\
\hline PEG & 31.5 & 38.9 & 29.6 & 70.4 & 0.16 & 37.9 & 54.2 & 50.5 \\
\hline Silage & 24.5 & 47.6 & 27.9 & 72.1 & 0.24 & 49.6 & 59.2 & 54.8 \\
\hline \multicolumn{9}{|l|}{ Lycium shawii } \\
\hline As fed & 32.5 & 37.9 & 29.5 & 70.5 & 0.24 & 43.6 & 64.0 & 61.1 \\
\hline PEG & 1.5 & 60.2 & 38.4 & 61.6 & 0.24 & 63.9 & 50.9 & 46.2 \\
\hline Silage & 34.9 & 45.9 & 19.2 & 80.8 & 0.17 & 49.5 & 70.0 & 65.7 \\
\hline \multicolumn{9}{|l|}{ Asphodelus } \\
\hline Fistulosus & 31.4 & 60.9 & 7.7 & 92.3 & 0.23 & 64.6 & 81.5 & 76.7 \\
\hline As fed & 41.7 & 48.4 & 9.9 & 90.1 & 0.28 & 53.7 & 82.7 & 79.2 \\
\hline PEG & 37.8 & 54.4 & 7.8 & 92.2 & 0.20 & 58.0 & 81.4 & 76.7 \\
\hline \multicolumn{9}{|l|}{ Silage } \\
\hline \multicolumn{9}{|l|}{ Silybium marianum } \\
\hline As fed & 31.8 & 58.4 & 9.9 & 90.1 & 0.14 & 59.6 & 74.7 & 68.9 \\
\hline PEG & 17.5 & 72.0 & 10.5 & 89.5 & 0.15 & 71.5 & 70.6 & 63.6 \\
\hline Silage & 26.2 & 69.8 & 4.0 & 95.9 & 0.13 & 68.3 & 75.5 & 68.3 \\
\hline \multicolumn{9}{|c|}{ Pituranthos tortuosus } \\
\hline As fed & 21.7 & 42.6 & 35.7 & 64.3 & 0.13 & 54.2 & 52.0 & 47.6 \\
\hline PEG & 23.5 & 42.9 & 33.6 & 66.4 & 0.05 & 37.5 & 43.3 & 38.6 \\
\hline Silage & 23.4 & 43.2 & 33.4 & 66.6 & 0.12 & 45.5 & 53.8 & 49.3 \\
\hline \multicolumn{9}{|l|}{ Suaeda vermiculata } \\
\hline As fed & 23.5 & 50.3 & 26.2 & 73.8 & 0.12 & 51.4 & 58.7 & 53.3 \\
\hline PEG & 19.6 & 51.7 & 28.7 & 71.3 & 0.12 & 52.6 & 55.8 & 50.4 \\
\hline Silage & 31.2 & 53.1 & 15.8 & 84.2 & 0.12 & 58.6 & 77.3 & 73.9 \\
\hline$\pm \mathrm{SE}$ & 3.18 & 3.4 & 2.42 & 2.42 & 0.04 & 3.41 & 1.60 & 1.68 \\
\hline \multicolumn{9}{|l|}{ Significance } \\
\hline Plant & *** & $* * *$ & *** & $* * *$ & $* * *$ & $* * *$ & $* * *$ & $* * *$ \\
\hline Treatment & $* *$ & N.S & $* * *$ & $* * *$ & N.S & N.S & $* * *$ & $* * *$ \\
\hline Plant $\times$ treatment & $* * *$ & $* * *$ & $* * *$ & $* * *$ & $* * *$ & $* * *$ & $* * *$ & $* * *$ \\
\hline
\end{tabular}

ns: non significant, $\left({ }^{*}\right): P<0.05 ;\left(^{* *}\right): P<0.01 ;\left(^{* *}\right): P<0.001$

a: soluble fraction, b: slowly degraded fraction, U: insoluble fraction, c: degradation rate of fraction

$b$,

EDp: effective degradability of protein,

EDdm: effective degradability of dry matter. 


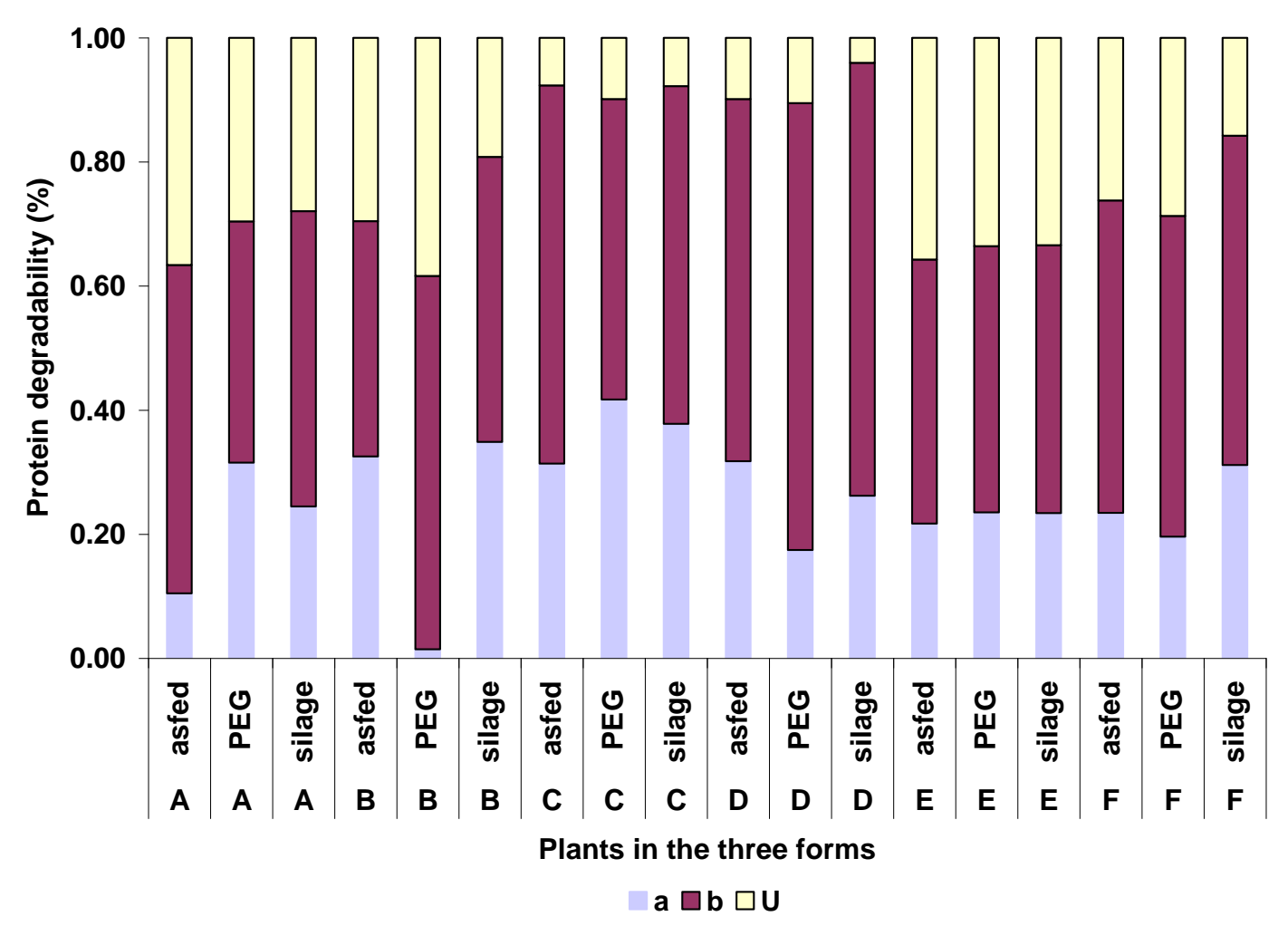

Plants:
A: Thymelaea hirsute
D: Silybium marianum
B: Lycium shawii
E: Pituranthos tortuous
C : Asphodelus Fistulosus
F: Suaeda vermiculata

Fig. (1). Effect of plant species and treatments on protein degradability kinetics (a, b and $U$ ).

\section{CONCLUSION}

The results of the present study showed that ensiling and treatment with PEG resulted in reducing the concentration of anti-nutritional factors. This study also revealed that forage plant species can not conveniently be utilized in formulating quality rations for maintenance and fattening of ruminant feeding because most of the evaluated plants in this study appear to have moderate to low CP and moderate $\mathrm{CF}$ with considerable concentrations of anti-nutritive factors causing un palatability of most of them. Also, degradation kinetics, which more related to the proportions of soluble and insoluble degradable fractions of DM were affected with treatments. No consistent differences in degradability rate were found among plants. Total degradability " $a+b$ " of DM was uniform among treatments regardless the plant species but more variable for $\mathrm{CP}$. Therefore, it can be concluded that these forage plants cannot be used as a sole diet, cannot be used as fed and hence there is a need for protein supplementation and for treatments to reduce their deleterios effects when fed to ruminants.

\section{Recommendations}

Based on the findings of this study, Thymelaea hirsuta ; Lycium shawii; Asphodelus fistulosus ; Silybium marianum; Pituranthos tortuosus and Suaeda vermiculata are recommended for inclusion in ruminant livestock feeding after appropriate treatment to alleviate their adverse effects on animal. Also, they must not be provided to animals as a sole diet because of their un acceptable levels of CP, tannins and saponins, so animals must be supplemented with proteins. It is a good sign that they are available all years round which provide either leaves or pods consumed by ruminants in the semi arid environment of North western part of Egypt. 


\section{ACKNOWLEDGEMENT}

The author thanks Dr Ahmed Askar, Professor of Animal Nutrition, Animal and Poultry Production Division, Desert Research Center, Egypt, for his positive support in the statistical analysis.

\section{REFERENCES}

Abdel Gawad, M. H. (2015). In situ dry matter , crude protein , fiber degradation and in vitro gas production of halophytic grass (Sporopolus virginicus) by arabian camel. Egyptian J. Anim. Prod. 52(1): 71-79.

A.O.A.C. (2005). Official Methods of Analysis. (18th Ed.), Association of Official Analytical Chemists, Arlington, VA, U.S.A.

Balbaa, S. I. (1969). Medicinal plant constituents . I, Cairo University Press, P. 92.

Barry, T.N. and W.C. McNabb (1999), “The implications of condensed tannins on the nutritive value of temperate forages fed to ruminants", British Journal Nutrition 81: 263-272

Barry, H.J. (1987). “Secondary compounds of forages”, In: Nutrition of herbivores. Hacker, J.B. and Ternouth, J. H. (eds) A. P. Sydney pp. 91- 120.

Ben Salem, H.; L. Ben Salem, and J.L. Tisser (2000). Deactivation of condensed tannins in Acacia cyanophylla linddl. Foilage by PEG infee blocks effect on feed intake, diet digestibility, nitrogen balance, microbial synthesis and growth by sheep. Livest Prod Sci 64: 51-64.

Boufennara, S.; L. Bouazza; S. López; H. Bousseboua, and R. Bodas (2013). Effect of polyethylene glycol addition on methane production from some Algerian browse plant species in an in vitro gas system. In: Options Méditerranéennes, A no. 107. Feeding and management strategies to improve livestock productivity, welfare and product quality under climate change.

Brown, W.; Z. Q. Fla and W. D. Pitman (1991). In vitro fiber digestion: association effects in tropical grass legume mixtures. Trop grasslands, 25: 297-304.

Canbolat, O.; A. Kamalak; E. Ozkose; C.O. Ozkan; M. Sahin and P. Karabay ( 2005). Effect of polyethylene glycol on in vitro gas production, metabolizable energy and organic matter digestibility of Quercus cerris leaves. In: Livestock Research for Rural Development. Volume 17, Article 42.

Cardozo, P.W.; S. Calsamiglia; A. Ferret and C. Kamel (2004), "Effects of natural plant extracts on ruminal protein degradation and fermentation profiles in continuous culture', Journal of Animal Science 82, 2336-3230.

Colombatto, D.; F.L. Mould; M.K. Bhat; R.H. Phipps and E. Owen. (2004). In vitro evaluation of fibrolytic enzymes as additives for maize (Zea mays L.) silage: II. Effects on rate of acidification, fibre degradation during ensiling and rumen fermentation. Anim. Feed Sci. Technol. 111, 111-128.

Costa, R. F.; D. A. A. Pires; M. M.A. Moura; J. A. S. Rodrigues; V. R. R. Júnior, and D. C. Tolentino (2016). In situ degradability of dry matter and fibrous fraction of sorghum silage. Acta Scientiarum. Animal Sciences Maringá, v. 38, n. 2, p. 171- 176, Apr.-June.

El-Morsy, M.H.M. (2010). Relative importance of salt marshes as range resources in the north western Mediterranean coast of Egypt. Journal of Phytology 2(3): 39-50

El-Morsy, M.H.M. and S. T. H. Ahmed (2010). Studies on plant cover of wadi Umm el-Rakham in the Northwestern coast of Egypt. Journal of Phytology, 2(3): 73-86

El-Waziry, A.M.; M.E.A. Nasser; S.M.A. Sallam; A. L. Abdallah, and I.C.S. Bueno ( 2007). Processing Methods of Soybean Meal 2. Effect of Autoclaving and Quebracho Tannin TreatedSoybean Meal on Gas Production and Rumen Fermentation in vitro. J. Appl. Sci. Res., 3: 17.

Fagg, C.W. and J. L. Stewart (1994). "The value of Acacia and Prosopis in arid and semi- arid environments', Journal of Arid Environments 27, 3-25. 


\section{El-Essawy}

FAO (1987). Fodder trees \& Shrubs in range and Feeding System in North Africa. Food Agricultural Organization (FAO), Rome.

Foley, W. J., G. R. Jason, and C. McArthur (1999). Role of secondary metabolites in the nutritional ecology of mammalian herbivores: How far have we come in 25 years? Pages 130-209 in Nutritional Ecology of Herbivores. H.-J. G. Jung and G. C. Fahey, Jr., ed. Am. Soc. Anim. Sci., Savoy, IL.

Gidado O. G.; A. Kibon; Z. A. Gwargwor; P. Mbaya and M. J. Baba (2013) . Assessment of antinutritive factors and nutrient composition of some selected browse plants used as livestock feeds in Taraba State. Inter. J. Appl. Sci. Engr, 1(1):5-9.

Givens D.I. and H. Rulquin (2004). Utilization by ruminants of nitrogen compounds in silage-based diets. Anim. Feed Sci.Technol. 114, 1-18.

Gonazlez, J. and S. Andres (2003). Rumen degradability of some feed legume seeds. Anim. Res., 52: $17-25$.

Jenkins, K. J. and A. S. Atwal (1994). Effects of dietary saponins on fecal bile acids and neutral sterols, and availability of vitamins A and E in the chick. J Nutr Biochem 5(3): 134-137.

Jones, W.T.; L.B. Anderson and M. D. Ross (1973). Bloat in cattle: detection of protein precipitants (flavolans) in legumes. New Zealand J. Agric. Res., 16: 441-6.

Jones, W.T. and J. L. Mangan (1977). Complexes of the CT of ainfon (onobrycli viciae folia scoap) with fraction leaf protein and with sub maxillary mucoprotein and their reversal by PEG and $\mathrm{pH}$. J Sci Food Agric 28: 26-136.

Jones, R.J. and B. Palmer (2000). In vitro digestion studies using 14C-labelled Poly ethylene glycol (PEG) 4000: comparison of six tanniniferous shrub legumes and the grass Panicum maxicum. In: Animal Feed Science and Technology, 86, p. 215-221.

Jones, R.J. and J. B. Lowry (1991). Overcoming problems of fodder quality in agroforestry systems. Chapter 14, In: Applications of Biological Research in Asian Agroforestry. Winrock International, Institute for Agricultural Development, Morrilton, Arkansas, USA.

Khan, M.A.; Z. Iqbal; M. Sarwar; M. Nisa; M.S. Khan; W. S. Lee; H. J. Lee and H. S. Kim (2006). Urea treated corncobs ensiled with or without additives for buffaloes: Ruminal characteristics, digestibility and nitrogen metabolism. Asian Austral. J. Anim. Sci. 19, 705-712.

Kumar, R. and M. Singh (1984). Tannins their adverse role in ruminant nutrition. J Agric Food Chem 32 (3): 447-453.

Kumara Mahipala, M. B. P.; G.L. Krebs; P. McCafferty; L.H.P. Gunaratnee (2009). Chemical composition, biological effect of tannin and in vitro nutrition value of selected browse species grown in the West Australian Mediterranean environment. Animal Feed Sci Technol 153(3-4): 203-215.

Le Houerou, H.N. (1980). Chemical composition and nutritive value of browse in West Africa. In: Le Houerou, H.N. (ed.), Browse in Africa. ILCA, Addis Ababa, Ethiopia, p. 261- 290.

Liman, A.A.; I. H. Malgwi; H. D. Nyako; B. A. Ardo; I. D. Mohammed; A. A. Yahya; M. Antiev; A. I. Zarah; M. M. Yahya and S. Abdullahi (2016). Nutrient evaluation and degradation characteristics of some browse plants in taraba state, Nigeria. International Journal of Information Research and Review, 3(1): 1612-1617

Llamas-Lama, G and D. K. Combs (1990), "Effect of alfalfa maturity on fibre utilization by high producing cows",Journal of Dairy Science 73: 1067-1080

Lowry, J.B. (1989). Toxic factors and problems: methods of alleviating these in animals. In: C. Devendra (Ed) Shrubs and Tree Fodders for Farin Animals. IDRC, Ottawa, Canada. pp 76-88.

LU, C. D. and N. A. Jorgensen (1987). Alfalfa saponins affect site and extent of nutritional digestion in ruminant. J Nutr 117(5): 919-927.

Makkar, H.P.S. (2003). Quantification of Tannin in Tree and Shrub Legumes. A Laboratory Manual. Kluwer Academic Publishers, Netherlands. 
Makkar, H.P.S. (2003b). Effects and fate of tannins in ruminant animals, adaptation to tannins and strategies to overcome detrimental effects of feeding tannin-rich feeds. Small Rum. Res. 49: 241 256.

Makkar , H. P. S. and K. Becker (2000). Beneficial effects of saponins on animal production. In Saponins in food and feedstuffs and medicinal plants (ed. W. Oleszek and A Marston), pp

Makkar H.P.S., M. Blümmel and K. Becker (1995). In vitro effects and interactions of tannins and saponins and fate of tannins in rumen. J. Sci. Food Agric. 69, 481-493.

McSweeny C.S.; B. Palmer; D.M. McNeill and D.O. Krause (2001). Microbial interaction with tannin: nutritional consequences for ruminants. Anim. Feed Sci. Technol. 91, 83-93.

Mehrez, A.Z., and E.R. Ørskov. (1977). A study of artificial bag technique for determining the digestibility of feed in the rumen. Journal of Agricultural Science 88:645-650.

Mupangwa, J.W.; N.T. Ngongoni and H. Hamudikuwanda (2003). "The effect of state of growth and method of drying fresh herbage on in sacco dry matter degradability of three tropical forage legumes". Livestock Res. Rural Dev. 15(2).

McMahon, L. R., T. A. McAllister, B. P. Berg, W. Majak, S. N. Acharya, J. D. Poppi, B. E. Coulman, Y. Wang, and K. J. Cheng (2000). A review of the effect of forage condensed tannins on ruminal fermentation and bloat in grazing cattle. Can. J. Plant Sci. 80:469-485.

Morrison, I. M. (1979). Changes in the cell wall components of laboratory silages and the effect of various additives on these changes. J. Agric. Sci. Camb. 93:581-586.

Newman, Y. C.; L. E. Sollenberger; W. E. Kunle and D. B. Bates (2002). Crude protein fractionation and degradation parameters of Limprograss herbages. Agronomy J. 94:1381-1382.

Njidda, A. A. and E. A. Olatunji (2012). Chemical Composition, Anti nutritive Substances and in Situ Digestion Kinetics of Four Ziziphus Specie Leaves use as Fodder for Ruminants in Semi Arid Zone of Nigeria. Journal of Natural Sciences Research. Vol.2, No.7.

Njidda, A.A.; I. Ikhimioya and C. E. Isidahomen (2013). In situ crude protein degradation and mineral composition of browse forages of semi - arid Nigeria. Inter J Agri Biosci, 2 (5): 286 296.

Norton, B.W. (1998), "The nutritive value of tree legumes", In: Gutteridge, R.C., Shelton, H.M. (Eds.), Forage trees legumes in Tropical Agriculture. Tropical Grassland Society of Australia Inc., St Lucia Queensland.

Okwu, D.E. and N.S. Ukanwa (2007). Nutritive value and phytochemical contents of fluted pumpkin (Telfaria occidentalis Hook f.) vegetable grown with different levels of Turkey droppings. African Crop Science Conference Proceedings, 8:1759- 1964.

Ørskov, E.R., and I. McDonald (1979). The estimate of protein degradability in the rumen from incubation measurements weighted according to rate of passage. Journal of Agricultural Science 92:499-503.

Pathak, A. (2008). Various factors affecting microbial proteins synthesis in the rumen. J.Vet. World. 1 (6): $186-189$.

Porter, L.J.; L.N. Hrstich and B.G. Chan (1986): The conversion of procyanidins and prodelphinidins to cyaniding and delphinidin. Phytochemistry 1: 223- 230.

Rezaei, J.; Y. Rouzbehan and H. Fazaeli (2009). Nutritive value of fresh and ensiled amaranth (Amaranthus hypochondriacus) treated with different levels of molasses. Anim. Feed Sci. Technol. 151, 153-160.

Roeder, E. (1995). Medicinal plants in China containing pyrrolizidine alkaloids. Pharmazie 50: 83-98.

Rubanza, C.D.K.; M.N. Shem; R. Otsyina; S.S. Bakengesa; T. Ichinohe and T. Fujihara (2005). Polyphenolics and tannins effects on in vitro digestibilty of selected Acacia species leaves. In: Animal Feed Science and Technology, 119, p. 129-142.

Salem, A.Z.M.; P.H. Robinson; M. M. El-Adawya; A. A. Hassan (2007). In vitro fermentation and microbial protein synthesis of some browse tree leaves with or without addition of polyethylene glycol. Animal Feed Science and Technology 138(3-4): 318-330. 


\section{El-Essawy}

Schwab, C.G. (1995). Protected proteins and amino acids for ruminants. In: Wallace, R. J, Chesson, A. (EDs), Biotechnology in Animal Feeds and Animal Feeding. VCH press, Weinhein, Germany, pp: $115-141$.

Sen, S.; H.P.S. Makkar and K. Becker (1998b). Alfalfa saponins and their implication in animal nutrition. Journal of Agricultural and Food Chemistry 46, 131-140.

Silanikove, N., Z. Nitsan, and A. Perevolotsky (1994). Effect of a daily supplementation of polyethylene glycol on intake and Digestion of tannin-containing leaves (Ceratonia siliqua) by sheep. J.Agric. Food Chem. 42:2844-2847.

Singh, B.; and H.P.S. Makkar (1993). "Plants cell wall digestion in ruminant - A review", International Journal of Animal Science. 7: 147-157.

Tamminga, S.; W.N. Van Straalen; A.P.J. Subunel; R.G.M. Meijer; A. Steg; C.J.G. Wever and M. C. Block (1994). "The Dutch protein evaluation system: the DVE/OEB system", Livestock Production Science, 40, 139-155.

Thomas, C. (2004)."Feed into Milk": A New Applied Feeding System for Dairy Cows. Nottingham University Press, Nottingham, UK, p. 72.

Valderrama, X. L. and R. G. Anrique (2011). In situ rumen degradation kinetics of high-protein forage crops in temperate climates. Chilean journal of agricultural research 71(4) OctoberDecember.

Vanzant, E.S.; R.C. Cochran; E. C. Titgemeyer; S. D. Stafford; K.C. Olson; D. E. Johnson; G.St. Jean (1996). In vivo and in situ measurement of forage protein degradation in beef cattle, J. Anim. Sci. (74) 2773-2784.

Waghorn, G. C.; I. D. Shelton and W. C. McNabb (1994). Effects of condensed tannins in Lotus pedunculatus on its nutritive value for sheep. 1. Non-nitrogenous aspects. J. Agric. Sci. 123:99107.

Wallace, R.J.; L. Arthaud and C. J. Newbold (1994). Influence of Yucca schidigera extract on ruminal ammonia concentrations and ruminal microorganism. Applied and Environmental Microbiology 60, 1762-1767.

Wallace, R.J. and M. A. Gotta (1988). Metabolism of nitrogen containing compounds In: Hobson, PN (ed). The rumen microbial ecosystem. Elsevier science publishing. New York, USA. p: 217-250.

Wilson, J.R. (1994). Cell wall characteristics in relation to forage digestion by ruminants. J. Agricultural Science, Cambridge, 122: 173 - 182.

Wina, E. (2010). Utilization of tannin containing shrub legumes for small ruminant production in Indonesia. Wartazoa, $20: 1$.

Yacout, M.H.M. (2016) Anti-Nutritional Factors \& Its Roles in Animal Nutrition. J. Dairy Vet. Anim. Res. 4(1): 00107. DOI: 10.15406/jdvar.2016.04.00107. 
تأثير بعض المعاملات علي هام المادة الجافة و البروتين الخام بطريقة أكياس الألياف الصناعية لبعض البرات نباتات المراعي بمنطقة الساحل الثمالي الغربي ـ مصرم المرافة ولئر

\author{
عبير كما عبد الحليم العيسوي \\ شعبة الإنتاج الحيواني و الدواجن- مركز بحوث الصحراء ـ الدطرية ـ القاهرة ـ مصر
}

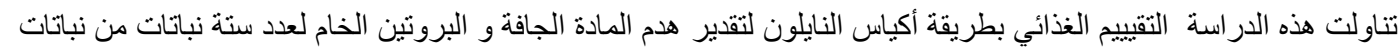

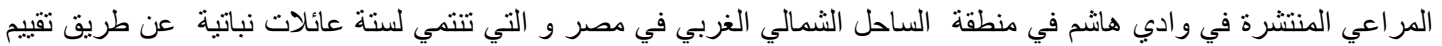

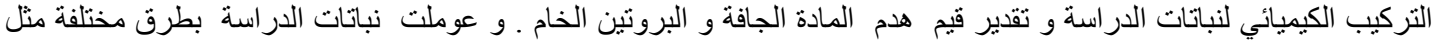

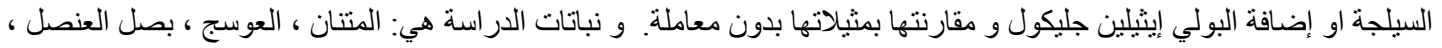

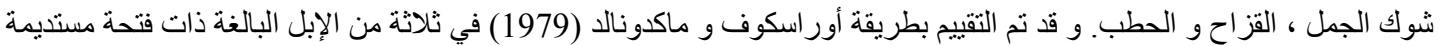

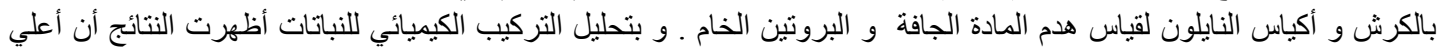

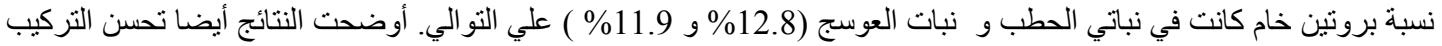

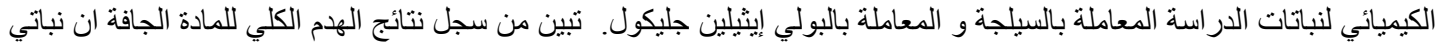

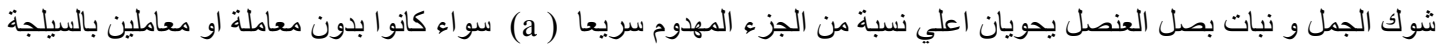

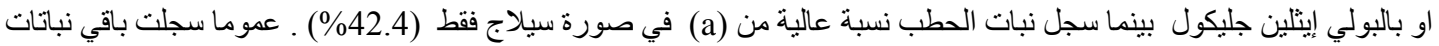

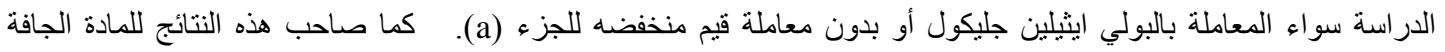

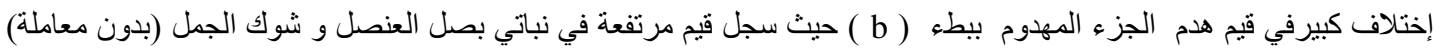

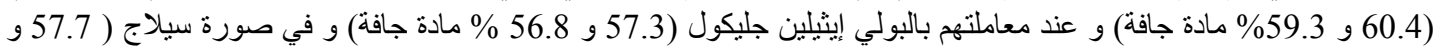

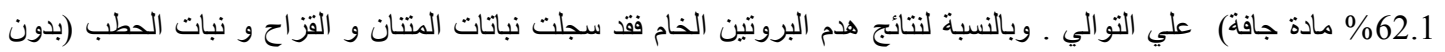

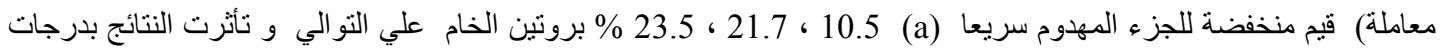

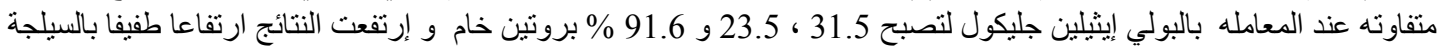

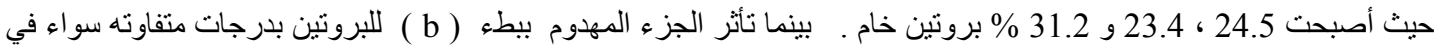

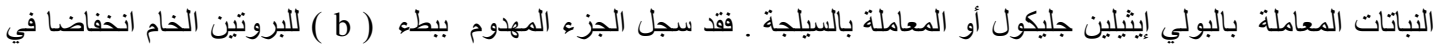

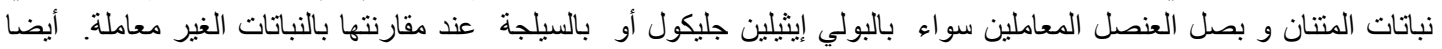

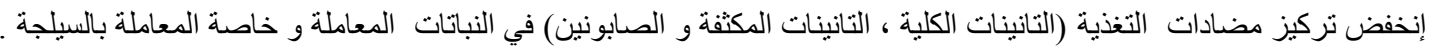
و بناء علي هذه النتائج نستخلص ان النباتات محل الدراسة ذات قيمة غذائية جيدة و يمكن استخدامها كمكل غذائي في صورة سيلاج. 